\title{
IMPACT OF BOARD STRUCTURE AND FIRM PERFORMANCE ON CHIEF EXECUTIVE'S COMPENSATION
}

\author{
Mohsin Ali Patel \\ Institute of Business Administration, \\ Karachi, Pakistan \\ E-mail: mpatel@iba.edu.pk
}

\begin{abstract}
The corporate board usually influences all important decisions of a firm including setting of its long-term goals, developing a corporate strategic policy, as well as hiring and setting the compensation of the chief executive. Moreover, the organization of the board may have a significant effect on the monitoring and governance of the company. This paper analyses the impact of structure of the board and firm performance on chief executive compensation, in an emerging economy context specifically, Pakistan. Chief executive compensation is one of the controversial and sought after topics in research nowadays. Interestingly, the exploration into the topic has found that there is a significant and positive impact of the non-executive directors serving on the corporate boards on the compensation of chief executive. Furthermore, the size of the board has also showed to have a significant and positive impact on the chief executive's compensation which logically means that the companies in which the boards are larger than the mean size will relatively pay higher to their chief executives. Also it was found that the performance of the firm does not have a statistically significant impact on chief executive compensation. These results have policy implications and are important to corporate stakeholders.
\end{abstract}

Keywords: corporate governance, board structure, firm performance, Pakistan.

ARTICLE INFO

Article History:

Received: 2 March 2019

Accepted: 12 July 2019

Published: 31 August 2019 


\section{INTRODUCTION}

From managing and supervising important company's affairs to providing entrepreneurial leadership, the board of directors has many functional and legal responsibilities towards a company. The board impacts many important decisions of a firm including setting of its long-term goals and developing a strategic policy. Sometimes, the board's opinion has a much greater impact on the top management's decision. That is, when a company enters into a new business or makes a big investment, the senior staff and CEO relies heavily on individual directors for expert advice and maintaining personal relationships with external parties. Individual directors use their external contacts with the business leaders for the advancement of the company. Moreover, they may sometimes become deeply involved in the day-to-day operations of a company, especially when it is facing sustained decline in its net income or there is a new managing director in a firm (Chitayat, 1984).

The composition, structure and style of the boardroom also impact company performance. While staggered boards are linked with low debt-tocapital ratio (Jiraporn \& Liu, 2008); companies with small boards are linked with taking risky investments (Wang, 2012). The board style is also linked with many key performance indicators including return on equity and assets. The organization of the board has a significant effect on the monitoring and corporate governance of a company. Shareholders appoint board of directors and so, the major objective of the board and its Chairman is to maximize shareholder wealth in the short-run as well as in the long-run. The board ensures that the agency issue between shareholders and management is minimized, so that right decisions are taken at the right time to develop a base for sustainable shareholder well-being maximization. Many laws and public reforms have now been formed and introduced to protect the right of shareholders and tighten corporate governance.

Corporate governance for emerging economies is a topic of vital importance (Patel, 2018). The purpose of this research is to investigate the role that board structure plays in determining the compensation of top management and also the impact, if any, of the firm's financial performance on the compensation, in the context of an emerging economy i.e. Pakistan. This topic is much important for the emerging economies because they have different dynamics and are closely controlled (Shah, 2011), so due to 
this, the research results of developed economies cannot be used for policy development in an emerging economy context. Furthermore, Pakistan's code of corporate governance was announced in 2001 but lacks complete implementation (Mir \& Nishat, 2004).

Executive remuneration is one the most debated topics in corporate governance, academics, policymaking and media (Conyon, 2006). There are many determinants of executive compensation including company's performance, corporate governance, power of the individual directors, and industry in which the company operates. This papers aims to determine one of these factors - the structure of the board of directors.

\section{LITERATURE REVIEW}

With the advent of technology, the corporate world is becoming more and more dynamic. Not only consumer preferences are changing but business models are also completely being revamped. These changes also impact the way the boards and their directors operate and also their role and responsibilities towards the company and the shareholders. For example, in the world of increasing globalization, bureaucratic companies are becoming "hallmarks of modern society" (Zald, 1969). The board of directors of these companies, consequently, have great potential power.

The power of the board also differs depending on the nature of industry, company and the country it operates. For example, in Argentina, companies have evolved from shareholders being mostly the directors to a more complex management and board function. The scope of power of the board has expanded from the past in the country. Meanwhile, in New York, the traditional concept of board or management was of unrestricted authority. The board had unlimited power. However, now the board authority has been restricted through different laws and reforms (Horvath, 1969). As the world is becoming more culturally, technologically and socially advanced; people are becoming more acceptable of change and diversity, even in the board rooms. A study on Canadian companies found that women are increasingly serving as board members in both public and private sector. These women have personal contacts to come to this position as well as a good track record and past corporate experience (Burke, 1997). The representation of 
minorities - women - in the board is also linked with different key metrics including executive and non-executive compensation (Shin, 2012). As more companies are becoming larger in size and are venturing into different geographical areas, the role of the board of directors of big multinationals is evolving. The board of foreign-based companies has three distinctive responsibilities; legal, internal and external (Leksell \& Lindgren, 1982).

According to Patel (2018), the agency theory about the divorce between ownership and control provide the ground breaking work for drawing upon the basic concepts of governance. The board should try to reduce the agency costs and conflicts between owners i.e. the shareholders and the executive. The internal roles of the board refer to the strategy formulation and execution, and monitoring and controlling of results and management's performance. It also relates to the integration efforts that maintain communication and coordination between different internal groups and business units. According to Leksell and Lindgren (1982), the board has both a passive and an active role in decision making. The board either serves as an advisor or counsel to the management or take an active part in maintaining a healthy relationship with the outside parties.

According to Shah (2011), the businesses in emerging economies like Pakistan have different dynamics. They are usually closely owned and controlled by people within the family. These families try their best to keep the business information to themselves, without disclosing to outsiders. These families have their own governance system and philosophy in place.

In additional, the board also serves as a source of discipline for the company. They ask discerning questions from management in certain situations and ensure that the company survives any crisis situation (Conard, Mace, Blough, \& Gibson, 1971). The primary role of the board of directors is to protect shareholders' interest. The board of large companies provides a safeguard to the stockholders for managerial employment contracts and the firm's equity capital. The board serves as an important internal control for the company as they closely monitor management's performance and takes part in strategic decision making (Baysinger \& Hoskisson, 1990). This helps to minimize the agency issue between management and the owners of the company. 
The structure and style of the board of directors are also associated with many key performance metrics of the company. For example, the presence of institutional holders has a positive impact on the company's ROE (Chaganti \& Damanpour, 1991). Thus, while boards might seem as being homogenous and fairly simple from the outside, they are "internally differentiated and fairly complex social organizations." A board whether small or large has the power to guide the company and to give it a future long-term direction (Hill, 1995).

Although some studies show an association between the company's performance and board structure, the relationship has not been consistent with other studies. According to Dalton, Daily, Ellstrand, and Johnson (1998), the board composition and leadership do not have any "substantive relationship" with the company's financial performance. While a company's performance and the structure of the board might not be strongly link, they both are certainly associated with the top management's compensation of a company. A study on Malaysian companies (ranging from 307 in 1979 to 795 in 2000) listed on the Kuala Lumpur Stock Exchange (KLSE) between 1989 and 2000 showed that while top management's pay was positively linked with the company's sales revenue, it was negatively associated with the concentration of the ownership on the company's board (Dogan \& Smyth, 2002).

Executives' remuneration is a multifaceted phenomenon that is determined by many factors including industry characteristics, firm's size, ownership structure, individual characteristics, industry regulations, and market growth (Barkema \& Gomez-Mejia, 1998). Growth and size of the company are also important determinants of top managements' pay (Ciscel, 1974).

Firm performance is positively linked with executive compensation as there is strong evidence that market and accounting returns affect executive remuneration (Canarella \& Nourayi, 2008). According to a study that analysed data of Indian companies, a company's current year accounting returns does not only positively impact CEO's compensation but the relation is "marginally significant" (Ghosh, 2006). The study revealed that for every $1 \%$ rise in the company's return on assets (ROA), CEO compensation in India increased by almost $0.47 \%$. This indicates that top management pay 
is strongly linked with company's overall performance. A study conducted by Sheikh, Wang, and Khan (2013) on the data of Pakistan, showed that the board size is positively, related to firm performance whereas outside directors are negatively related to the firm's performance. Also, according to Patel, Shamsi and Asim (2018), market capitalization and return on assets have a major impact on executive compensation.

The increasing competition is forcing companies around the world to become more careful about their cash flows. As compensation of executives, fixed or variable, makes up a huge portion of companies' expenditure, the decision regarding top management pay is one now of the most important decisions for any company, whether large or small. The importance of determining executive compensation can be seen from a study that shows that $89 \%$ of the total 232 large UK companies used an outsider consultant to determine the remuneration of their executives (Conyon, Peck, \& Sadler, 2011). Around sixty-three percent of the 232 companies used more than one consultant to compute top management pay.

Following several corporate scandals in the early 2000s and the Sarbanes-Oxley Act of 2002, there have been many studies focusing on the importance of corporate governance and determination of executive compensation. The global events did not only bring loopholes in the determination of executive pay packages on the spotlight but also changed board requirements of many countries to enhance the oversight function and control of the board. Following the new reforms in US, many companies also lowered their executives' pay as governance by the board over seniorlevel management increased. For example; from a sample of 865 US firms, companies that were least compliant to corporate governance laws in 2002 lowered CEOs compensation significantly after the new reforms. The decrease was around $17 \%$ higher than the more compliant companies. The result suggested that the structure and procedures of the boards materially impact decision regarding CEOs pay (Chhaochharia \& Grinstein, 2009).

While some studies show a positive relationship between having inside directors in the board room and executive compensation, other studies believe the relationship to be either ambiguous or non-existent. Many of the new corporate governance reforms across the world encourage companies to have independent directors in its board as they assume it 
will bring more monitoring efficiency and would maximize shareholders value. However, the relationship between the dependence of director and the equity-based management compensation is found to be ambiguous (Kumar \& Sivaramakrishnan, 2008). While, dependent directors are found to be "relatively poor" in designing top management's incentive-efficient contracts; independent directors are also associated with inefficiency in terms of monitoring and compensation contract designing. According to Patel (2018) share ownership by directors and performance of the firm have a significant negative relationship. Further, there exists a negative relationship between independent directors and firm performance.

Mostly large companies are associated with higher payments to their managers and executives. According to an early study by Baker (1939), large companies in America pay higher dollar payments to their top management. It is a common perception that large, state-owned companies pay high remuneration to their top management; however, many studies have shown that small, private companies also reward their executives with huge amount. This is due to the increasing competition in the global market and a pressure to hire the most qualified executives for company's strategic and operational management. A study on Italian listed companies on the Milan Stock Exchange between 1995 and 2002 found that familyowned companies pay more cash to the board compared to the state-owned firms (Barontini \& Bozzi, 2011). The negative relationship was due to family-owned companies appointing family members on high pay and was consistent with other European and non-European studies. Moreover, Baker also believed that although large companies pay high dollar amount to their executives yet the pay to earnings ratio is quite low in these firms, compared to smaller companies.

\section{METHODOLOGY}

\section{Research Approach}

To conduct this study, a quantitative research methodology was used. A deductive research approach was used for this study. The quantitative methodology will help us uncover the relationship between different data variables. 


\section{Data Collection}

For the purpose of this study, secondary data was extracted from annual financial statements of the companies. This was downloaded from the company's official websites, portals and the website of Pakistan Stock Exchange.

\section{Sample}

The companies listed on the PSX - 100 (Pakistan stock exchange), was the population for this research study. The banking, insurance and financial institutions sectors were excluded for the purposes of sample selection, as this sector has different characteristics than the other sectors. The total number of observations were extracted from 50 companies for a five year period. The required data variables for this research were not completely or readily available on the data portals and needed to be handpicked for the research.

\section{Regression Model}

The following model was considered for the purpose of this study, considering executive compensation, dividends, firm performance and corporate governance variables. A one-year lag was used, as according to the previous researchers like Randøy and Nielsen (2002) compensation decisions of the current year were made on the basis of the previous year's structure and performance.

$$
\begin{aligned}
& \mathrm{Ln}(\text { CEO comp })_{\mathrm{t}}=\mathrm{a}+\mathrm{b}_{1} \ln (\% \text { of IND })_{\mathrm{t}-1}+\mathrm{b}_{2} \ln (\% \text { of NED })_{\mathrm{t}-1}+\mathrm{b}_{3} \\
& \ln (\text { Market Cap })_{\mathrm{t}-1}+\mathrm{b}_{4} \ln (\text { ROE })_{\mathrm{t}-1}+\mathrm{b}_{5} \ln (\mathrm{FS})_{\mathrm{t}-1}+\varepsilon_{\mathrm{it}}
\end{aligned}
$$

Where:

$$
\begin{array}{ll}
\text { CEO comp } & =\text { Total Chief Executive Officer's Compensation } \\
\% \text { of IND } & =\text { Percentage of Independent Directors }= \\
\% \text { of NED } & =\text { Percentage of Executive Directors } \\
\text { Market Cap } & =\text { Market Capitalization } \\
\text { ROE } & =\text { Return on Equity } \\
\text { FS } & =\text { Firm size }
\end{array}
$$




\section{Dependent and Independent Variables and their definition} of CEO

Chief Executive Compensation $=$ Natural log of the total compensation

Percentage of Independent Directors = Independent directors / Total directors on the board.

Percentage of Non-Executive Directors $=$ Non-Executive directors / Total directors on the board.

Market Capitalization $=$ No. of outstanding shares $\mathrm{x}$ Closing share price

ROA $($ Return on Assets $)=$ Log of $($ Net Profit after tax / Total Assets $)$

Size of the firm $=$ Log of Total assets (Control variable)

\section{DATA ANALYSIS}

\section{Descriptive Statistics}

The descriptive statistics in Table 1 below shows the mean value of the total CEO compensation to be Rs. $23,949,837$ and the median compensation is Rs. 18,000,000. Furthermore, interestingly Rs. 207,381,000 is the maximum compensation given to the $\mathrm{CEO}$ which is much higher than the mean compensation.

Table 1: Descriptive Statistics

\begin{tabular}{lccccc}
\hline & $\begin{array}{c}\text { Total CEO } \\
\text { Compensation }\end{array}$ & Board Size & $\begin{array}{c}\text { \% of } \\
\text { Independent } \\
\text { Directors }\end{array}$ & $\begin{array}{c}\text { \% of Non- } \\
\text { Executive } \\
\text { Directors }\end{array}$ & $\begin{array}{c}\text { Return on } \\
\text { Equity }\end{array}$ \\
\hline Mean & 23949837 & 9.000000 & 0.180852 & 0.546011 & 4.808097 \\
\hline Median & 18000000 & 8.000000 & 0.142860 & 0.571430 & 0.204200 \\
\hline Maximum & 207381000 & 21.00000 & 0.857140 & 0.928570 & 90.17000 \\
\hline Minimum & 0.000000 & 6.000000 & 0.000000 & 0.000000 & -2.470000 \\
\hline Std. Dev. & 23434717 & 2.399308 & 0.179576 & 0.216529 & 16.33857 \\
\hline
\end{tabular}


Similarly, the independent variables like, the board size has a mean value of 9, whereas there are boards which were much larger than this and had 21 members in total. The mean returns of the company i.e. ROE showed a mean return of $4.80 \%$. However, on the other hand there were also companies having losses which is evident from the minimum value $-2.47 \%$.

\section{Regression Analysis}

Table 2 presents the Fixed Effects specification results. The regression $\mathrm{R}^{2}$ value is shown to be $80 \%$ depicting the explanatory power of the model. It means that this model explains $80 \%$ of the variance in executive compensation. The F-statistic value is statistically significant i.e. 13.59 with a significant $\mathrm{p}$-value which is less than $5 \%$.

The market capitalization and percentage of Non-Executive directors have a significant impact on the dependent variable i.e. CEO compensation. The percentage of NED has a significant but negative impact whereas, the market capitalization has a positive impact on the executive compensation. However, all other variables are shown to have a statistically insignificant impact on compensation.

Table 2: Applying Fixed Effects

Dependent Variable: LNTOTAL_CEO_COMPENSATION

\begin{tabular}{lcccc}
\hline \multicolumn{1}{c}{ Variable } & Coefficient & Std. Error & t-Statistic & Prob. \\
\hline C & 9.892992 & 1.191059 & 8.306043 & 0.0000 \\
\hline LN Board Size(-1) & 0.538927 & 0.405466 & 1.329155 & 0.1853 \\
\hline \% of Independent Directors(-1) & -0.253930 & 0.354000 & -0.717316 & 0.4740 \\
\hline \% of Non-Executive Directors (-1) & -0.623683 & 0.324723 & -1.920661 & 0.0562 \\
\hline Return on Equity (-1) & -0.007147 & 0.006151 & -1.161878 & 0.2467 \\
\hline LN Total Market Capitalization (-1) & 0.264449 & 0.040383 & 6.548466 & 0.0000 \\
\hline R-squared & & 0.805462 & & \\
\hline F-statistic & & 13.59427 & & \\
\hline
\end{tabular}

Further, the random effects model was applied and the results are shown in the following Table 3. The random effects specification results 
show that three variables have statistically significant impact and have a value of less than 0.10 . These three variables include market capitalization, percentage of non-Executive directors and board size. All these have a significant impact on CEO compensation. Also as per the results in the Fixed Effects Model, the percentage of non-executive directors have a significant negative impact on compensation.

Table 3: Random Effects

\begin{tabular}{lcccc}
\hline \multicolumn{1}{c}{ Variable } & Coefficient & Std. Error & t-Statistic & Prob. \\
\hline C & 11.36520 & 0.836961 & 13.57913 & 0.0000 \\
\hline LN Board Size(-1) & 0.573590 & 0.285856 & 2.006568 & 0.0459 \\
\hline \% of Independent Directors(-1) & -0.203974 & 0.312006 & -0.653748 & 0.5139 \\
\hline $\begin{array}{l}\text { \% of Non-Executive Directors } \\
(-1)\end{array}$ & -0.514259 & 0.277758 & -1.851468 & 0.0653 \\
\hline Return on Equity (-1) & -0.002430 & 0.004178 & -0.581686 & 0.5613 \\
\hline $\begin{array}{l}\text { LN Total Market Capitalization } \\
(-1)\end{array}$ & 0.193765 & 0.029100 & 6.658672 & 0.0000 \\
\hline
\end{tabular}

After applying the Fixed Effects and Random Effects Model, we need to check the suitability of which of the above two is preferable. Thus, the Hausman Test was applied and the results are shown in Table 4 below showing that the probability value is insignificant, having a p-value of 0.1905 , which is more than 0.05 ; so the null hypothesis cannot be rejected and we can conclude that the Random Effects Model is more appropriate in this research study.

Table 4: Applying Hausman Test

Correlated Random Effects - Hausman Test

\begin{tabular}{cccc}
\hline Test Summary & $\begin{array}{c}\text { Chi-Sq. } \\
\text { Statistic }\end{array}$ & Chi-Sq. d.f. & Prob. \\
\hline Cross-section random & 7.431206 & 5 & 0.1905 \\
\hline
\end{tabular}

Table 5 shows the results of the Generalized Method of Moments (GMM) estimation technique, which was formalized by Professor Hansen (1982). Currently, it is the most popular method of estimation for reducing the possible data problems like endogenity, autocorrelation and heteroscedasticity in the data. This technique can be applied if the collected 
research data comprises of a lesser time period and with more cross sections in it i.e. $\mathrm{T}<\mathrm{N}$ which is present in our data so we can appropriately use this GMM model.

$\begin{aligned} & \text { Table 5: Generalized Method of Moments (GMM) } \\
& \text { Dependent Variable: LNTOTAL_CEO_COMP } \\
& \text { Method: Panel Generalized Method of Moments }\end{aligned}$
\begin{tabular}{|l|c|}
\hline J-statistic & 0.031902 \\
\hline pval result & 1.000 \\
\hline
\end{tabular}

The J-statistic (J-stats) value is shown to be 0.0319 showing the model is fit. Further, the scalar p-value was calculated which is 1.000. Since this is higher than the value of $0.05 \mathrm{o}$ we fail to reject the null hypothesis and conclude that the instruments are valid and the model is appropriately specified and fit.

\section{CONCLUSION}

The purpose of this research was to find the impact of structure of the board and firm's performance on CEO compensation. Interestingly, the results show that in Pakistan there is a significant and positive impact of non-executive directors serving on the board on CEO compensation. Similarly, the board size also showed to have a significant positive impact on CEO compensation. This means that the CEO's are paid higher in the companies in which boards are larger than the mean size. This may be due to the lobbying, loss of directors' control or problems in building consensus in controlling and reducing the executives' compensation. On the other hand, the performance of a firm does not show to have a statistically significant impact on CEO compensation. However, market capitalization has a significant positive impact on compensation. This means that size of the firm does contribute to variations in compensation and that larger firms will usually pay more to their CEO's.

Future research in this area can be expanded by increasing the size of the data as well as accessing the data of companies in other countries in the Asia-Pacific region. 


\section{REFERENCES}

Baker, J. C. (1939). Executive compensation payments by large and small industrial companies. The Quarterly Journal of Economics, 53(3), 404-434.

Barkema, H. G., \& Gomez-Mejia, L. R. (1998). Managerial compensation and firm performance: A general research framework. The Academy of Management Journal, 41(2), 135-145.

Barontini, R., \& Bozzi, S. (2011). Board compensation and ownership structure: Empirical evidence for Italian listed companies. Journal of Management and Governance, 15, 59-81.

Baysinger, B., \& Hoskisson, R. E. (1990). The composition of boards of directors and strategic control: Effects on corporate strategy. The Academy of Management Review, 15(1), 72-87.

Burke, R. J. (1997). Women on corporate boards of directors: A needed resource. Journal of Business Ethics, 16(9), 909-915.

Canarella, G., \& Nourayi, M. (2008). Executive compensation and firm performance: Adjustment dynamics, non-linearity and asymmetry. Managerial and Decision Economics, 29, 293-315.

Chaganti, R., \& Damanpour, F. (1991). Institutional ownership, capital structure, and firm performance. Strategic Management Journal, 12(7), 479-491.

Chhaochharia, V., \& Grinstein, Y. (2009). CEO compensation and board structure. The Journal of Finance, 64(1), 231-261.

Chitayat, G. (1984). The role of the board of directors in practical terms. Management International Review, 24(1), 71-77.

Ciscel, D. H. (1974). Determinants of executive compensation. Southern Economic Journal, 40(4), 613-617. 
Conard, A. F., Mace, M. L., Blough, R., \& Gibson, G. D. (1971). Functions of directors under the existing system. The Business Lawyer, 27, 23-46. Retrieved from http://www.jstor.org/stable/40684847

Conyon, M. J. (2006). Executive compensation and incentives. Academy of Management Perspectives, 20(1), 25-44.

Conyon, M. J., Peck, S. I., \& Sadler, G. V. (2011). New perspectives on the governance of executive compensation: An examination of the role and effect of compensation consultant. Journal of Management and Governance, 15(1), 29-58.

Dalton, D. R., Daily, C. M., Ellstrand, A. E., \& Johnson, J. L. (1998). Meta-analytic reviews of board composition, leadership structure, and financial performance. Strategic Management Journal, 19(3), 269-290.

Dogan, E., \& Smyth, R. (2002). Board remuneration, company performance, and ownership concentration: Evidence from publicly listed Malaysian companies. ASEAN Economic Bulletin, 19(3), 319-347.

Ghosh, A. (2006). Determination of executive compensation in an emerging economy: Evidence from India. Emerging Markets Finance \& Trade, 42(3), 66-90.

Hill, S. (1995). The social organization of boards of director. The British Journal of Sociology, 46(2), 245-278.

Horvath, P. A. (1969). The organization and functions of the board of directors of corporations in Argentina and the United States. Lawyer of the Americas, 1(3), 1-23.

Jiraporn, P., \& Liu, Y. (2008). Capital structure, staggered boards, and firm value. Financial Analysts Journal, 64(1), 49-60.

Kumar, P., \& Sivaramakrishnan, K. (2008). Who monitors the monitor? The effect of board independence on executive compensation and firm value. The Review of Financial Studies, 21(3), 1371-1401. 
Leksell, L., \& Lindgren, U. (1982). The board of directors in foreign subsidiaries. Journal of International Business Studies, 13(1), 27-38.

Mir, S., \& Nishat, M. (2004). Corporate governance structure and firm performance in Pakistan: An empirical study. Paper presented at Second Annual Conference in Corporate Governance. Lahore University of Management Sciences, Lahore

Patel, M. A. (2018). Corporate governance and financial performance in an emerging economy context: Evidence from Pakistan's food, personal care and cement sectors. South Asian Journal of Management, 25(1), $7-22$.

Patel, M. A., Shamsi, A. F., \& Asim, M. (2018). Chief executive compensation-part and parcel of the agency problem: Empirical evidence From Pakistan. Asia-Pacific Management Accounting Journal. 13(1), 153-165.

Sheikh, N. A., Wang, Z., \& Khan, S. (2013). The impact of internal attributes of corporate governance on firm performance: Evidence from Pakistan. International Journal of Commerce and Management, 23(1), 38-55.

Shin, T. (2012). The gender gap in executive compensation: The role of female directors and chief executive officers. The ANNALS of the American Academy of Political and Social Science, 639(1), 258-278.

Wang, C.-J. (2012). Board size and firm risk-taking. Review of Quantitative Finance and Accounting, 38, 519-542.

Zald, M. N. (1969). The power and functions of boards of directors: A theoretical synthesis. American Journal of Sociology, 75(1), 97-111. 